\title{
Mycotic Aneurysm
}

National Cancer Institute

\section{Source}

National Cancer Institute. Mycotic Aneurysm. NCI Thesaurus. Code C35148.

An aneurysm caused by an infection. 